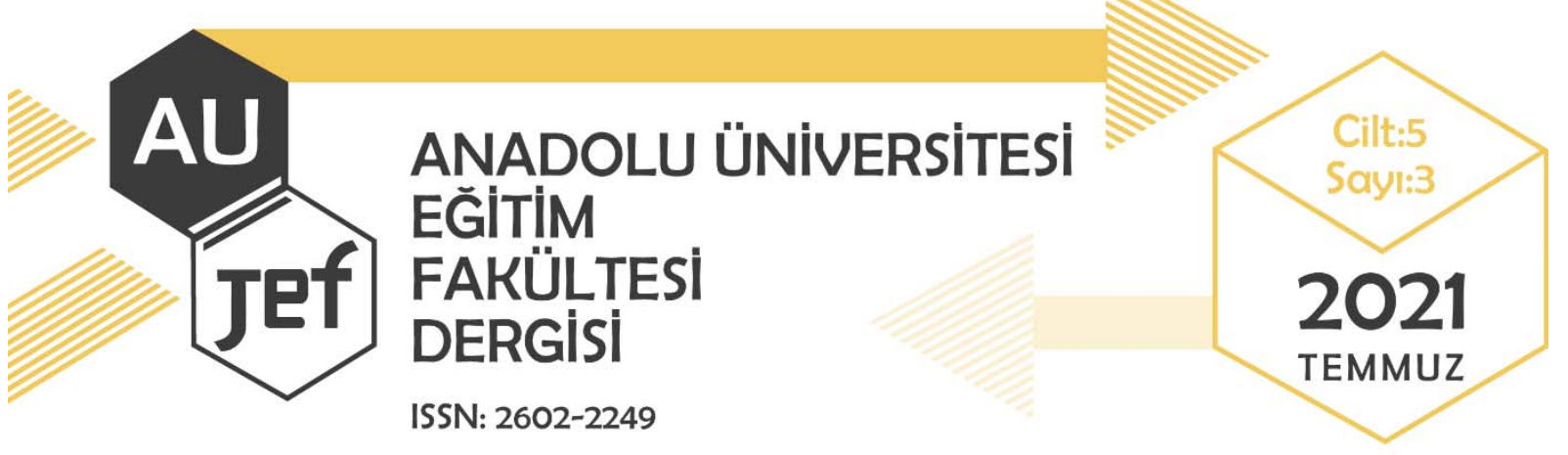

\title{
Hayat Bilgisi ve İlk Okuma Yazma Derslerini Konu Alan Doktora Tezlerine Yönelik Bir İnceleme
}

\author{
An Analysis of Doctoral Theses on Life Studies and Primary Literacy Courses \\ Bülent GÜVEN ${ }^{1}$, Emel KIRAT ${ }^{2}$
}

Makale Türü: Araştırma Makalesi

Başvuru Tarihi: 02.04.2021

Kabul Tarihi: 01.08.2021

Atıf İçin: Güven, B. ve Kırat, E. (2021). Hayat bilgisi dersi ve ilk okuma yazma öğretimini konu alan doktora tezlerine yönelik bir inceleme. Anadolu Üniversitesi Eğitim Fakültesi Dergisi (AUJEF), 5(3), 324-347.

ÖZ: Okul öncesi eğitimin ardından ilkokula geçişle birlikte tüm öğrencilerin öğretim sürecinde ilk kez karşılaştıkları hayat bilgisi ve ilk okuma yazma becerisinin ağıllıklı olduğu Türkçe derslerinin bireylere kazandırılması hedeflenen temel yaşam becerileri ve okula uyum süreçleri üzerinde doğrudan etkili olduğu açıkça söylenebilir. Her iki ders sahip oldukları misyonlar yönüyle programlarda yer aldıkları tarihten bugüne çok sayıda akademik çalışmaya konu olmuş, araştırmacıların üzerinde sıkça çalıştığı bir alan haline gelmiştir. Öyle ki ortaya konan birçok araştırma incelendiğinde program geliştirme uzmanlarına, uygulayıcı olan öğretmenlere önemli yardımlar sağlayabilmeyi amaçladıkları anlaşılmaktadır. $\mathrm{Bu}$ durumdan hareketle lisansüstü eğitim basamaklarından doktora düzeyinde anılan her iki derse yönelik gerçekleştirilen tez çalışmalarını temel araştırma boyutları yönüyle inceleyebilmek bu araştırmanın genel amacıdır. Nitel araştırma yöntemine uygun olarak doküman inceleme tekniği ile gerçekleştirilen araştırmada hayat bilgisi ve ilk okuma yazma dersleri konularında tamamlanmış YÖK Ulusal Tez Merkezi ve Proquest veri tabanında erişime açık bulunan doktora tezleri kapsama alınmıştır. Araştırmanın amaçlarına uygun şekilde belirlenen boyutlara bağlı olarak elde edilen araştırma verileri frekans ve yüzde değerleriyle sayısal hale getirilerek tablolar şeklinde sunulmuştur. Bulguların analizine dayalı olarak araştırma kapsamında incelenen doktora tezlerinin ağırlıklı şekilde beceri kazandırma, beceri düzeyinin belirlenmesi, kullanılan yöntem - tekniğin etkililiğinin sınanması gibi amaçlarla gerçekleştirildiği, araştırmacıların tercih ettikleri araştırma yöntemi yönüyle yüksek oranda karma yöntem ve bu yönteme bağlı desenlere yöneldikleri belirlenmiş̧ir. Gerçekleştirilen deneysel desen ve eylem araştırmalarında ağılıklı olarak akademik başarı düzeyinin artışı yönünde sonuçlara ulaşıldığı da ayrıca gözlenmiştir.

Anahtar sözcükler: Hayat bilgisi dersi, ilk okuma yazma öğretimi, lisansüstü eğitim

\begin{abstract}
With the transition to primary school after pre-school education, it can be clearly said that the Turkish lessons that all students encounter for the first time in the teaching process, which are based on life science and first literacy skills, have a direct effect on the basic life skills and school adaptation processes that are aimed to be acquired by individuals. Both lessons have been the subject of many academic studies since they took place in the programs in terms of their missions, and it has become a field that researchers frequently work on. So much

1 Prof. Dr., Çanakkale Onsekiz Mart Üniversitesi Temel Eğitim Bölümü, bulentg@,comu.edu.tr, https://orcid.org/0000-0002-8883-3028

${ }^{2}$ Uzman okul öncesi öğretmeni, emelkiratt@gmail.com, https://orcid.org/0000-0001-5152-7214
\end{abstract}


so that, when many researches are examined, it is understood that they aim to provide important assistance to curriculum development experts and teachers who are practitioners. From this point of view, it is the general purpose of this study to be able to examine the thesis studies conducted for both courses at the level of postgraduate education, in terms of basic research dimensions. In the research conducted with the document review technique in accordance with the qualitative research method, the doctoral theses completed on life studies lesson and first reading and writing subjects were included in the scope of the YÖK's National Thesis Center and accessible in the Proquest database. The research data obtained depending on the dimensions determined in accordance with the aims of the study were presented in the form of tables after being digitized with frequency and percentage values. Based on the analysis of the findings, it was determined that the doctoral dissertations examined within the scope of the research were mainly carried out for the purposes of gaining skills, determining the skill level, testing the effectiveness of the method and technique used, and that the researchers preferred highly mixed method and patterns based on this method. It was also observed that, in the experimental design and action researches, results were obtained mainly in the direction of increasing the academic achievement level.

Keywords: Life science lesson, teaching first reading and writing, postgraduate education 


\section{GİRIŞ}

Bireylerin topluma uyum sağlama becerilerini kazanma anlamında ilk planlı etkinliklere adım attığ 1 , gelişim özellikleri yönüyle hem bireysel hem de toplumsal açıdan dinamiklik kazanmaya başladığ 1 dönem temel eğitim basamağı olarak adlandırılmaktadır. Davranış ve düşünce ediniminin bir sistematik çerçevesinde gelişim göstermesi bu eğitim basamağındaki hedefler ve onlara ulaşmak için gerçekleştirilen işlevsel uygulamalar ile mümkün olabilmektedir. Durum böyle olmakla birlikte bu gelişimin devamlılığı için gerçekleştirilecek uygulamaların bir bütün olarak ele alınması, araştırma faaliyetlerinin sonuçlarından yararlanılması süreçte daha olumlu bir işleyiş sağlayabilecektir (Senemoğlu, 2015).

Bireylerin erken çocukluk yıllarında gelişim dönemlerine bağlı olarak gerçekleştirmeye başladığı beceri kazanımı yaşam boyu devam edecek yaşamsal döngüye de temel oluşturmaktadır. Belirli aşamaları takip eden bu süreç okul yıllarında uygulanan programlar çerçevesinde izlenebilmektedir. Temel eğitim sürecinde oluşması beklenen bu yapı öğrenme - öğretme süreçlerinin çok yönlü uyaranlarla desteklenmesi ve öğrencilerin üst basamaklara hazırlanması ile sağlanmaya çalışılmaktadır (Fazlığlu, 2011). Bireyleri hayata hazırlamak amacı doğrultusunda temel yaşam becerilerinin kazandırılmasıyla birlikte onların aynı zamanda toplum yapısına uyum sağlamalarına yardımcı olacak gerçek hayatın içerisinden etkinliklerle desteklenmeleri, toplumsal yaşama hazırlanmaları çok yönlü gelişimleri için ayrı bir önem taşır (Sukawati ve ark., 2020). Sözü edilen gelişim süreçleri ve beceri ediniminin işlevsel yapısı basamaklara uygun olarak hazırlanan programların ögeleri içerisinde hayat bulmaktadır. Bu yapının çağa uygun nitelikleri kapsaması toplumsal hedeflerle birlikte bu hedeflere yönelik birey ve toplum özelliklerini yansıtması temel beklentidir. Bu noktada toplumsal ve bireysel ihtiyaçlar göz önünde bulundurularak hedef, içerik, öğrenme - öğretme süreci ve ölçme değerlendirme boyutlarında iyileştirme ya da geliştirme çalışmaları yapılmakta, farklılaşan ders içeriklerine uygun bir şekilde gerçekleştirilen bu düzenlemeler ortak amaçlar doğrultusunda ilgili eğitsel süreçlere yansitılmaktadır (Demirel, 2015).

Söz konusu planlamalar benimsenen yaklaşım ve hedefler doğrultusunda ders içeriklerine yansıyarak uygulama boyutunda işlerlik kazanmaktadır. Bilgiye ulaşma, geliştirme ve etkin bilgi kullanımına yönelik beceri kazanma özelliği evrensel öğrenme firsatlarıyla birlikte toplumsal yapı için gerekli ve günümüzde artık zorunlu bir duruma dönüşmüştür. Bu yapının sağlıklı şekilde oluşabilmesi eğitsel süreçlere yönelik gerçekleştirilen ileri araştırma sonuçlarının hazırlanan programlara yansıtılması ile mümkün olabilmektedir (Akcaalan ve Arslan, 2016).

Gözel (2021) öğrencilere kazandırılan toplumun temel değerlerinin yanı sıra sunulan öğretim aracılığıyla milli ve manevi değerlerin yaşamsal süreçlere aktarmını vurgulamıştır. Programlar içerisinde yer alan bu değerlerin aktarılma süreçleri kullanılan materyaller, öğretim yöntem ve teknikleri kapsamında benimsenen yaklaşım doğrultusunda ihtiyaçları karşılamaktadır.

Temel eğitim kapsamında anılan bu beceri ve içerikler ağırlıklı olarak hayat bilgisi, ilk okuma yazma gibi uygulamaların yer aldığı derslerde ele alınarak yaşam boyu öğrenme hedeflerinin kazandırılmasına zemin hazırlanmaktadır. Anılan bu derslerde öğrencilerin yaşama hazırlık anlamında önemli beceri ve nitelikler kazanmaları için önemli firsatlar sağlanmaktadır. 1926 yıllı ilkokul programı ile ilk kez karşılaştığımız gözlem, yaşama, iş ve deney (Binbaşığlu, 2003) dersi olarak programda tanımlanan Hayat Bilgisi dersi uygulanmaya başlandığı dönemden bugüne toplumsal değişim ve gelişime bağlı olarak ortaya konan paradigmaların etkisiyle işlevselliğini sürdüregelmiş bir ders olmuştur.

İlkokul dönemi içerisinde diğer derslerle öğrenme alanları doğrultusunda ilişkilendirilebilen hayat bilgisi dersi sosyal, bilimsel, teknik, felsefi boyutlarda öğrencilere etkin öğrenme firsatları sunmaktadır. 
Hayat bilgisi dersi aracılığıyla öğrenciler yaşamsal olayları eğitim - öğretim faaliyetleriyle bütünleştirebilmekte; öğrenme ve uygulayabilme, problem çözme gibi becerilerin kazanımına yönlendirilebilmektedir. Bu yeterlilikler kapsamında okul döneminin başlangıç yıllarında öğrencilere düşünme yolları öğretilmekte ve deneyim kazandırılmaktadır (Ministerium für Kultus, Jugend und Sport BadenWürttemberg, 2016).

Akademik ve toplumsal yaşamda temel bir ihtiyaç konumunda olan okuma - yazma faaliyetleri ilkokul yıllarının sonrasında devam eden eğitim hayatı ve sosyal yaşantının belirleyicisi olarak görülmektedir. Erbasan ve Erbasan (2020) okul yıllarının başında ilk okuma yazma sürecinde çocukların, velilerin ve ögretmenlerin çeşitli kaygılar taşıdığını ifade etmiştir. Bu kritik süreçte öğretmenler ve veliler de söz konusu kaygı ve sorunlara yönelik tedbirlere ve çözüm yollarına odaklanmaktadır.

Karatay, Külah ve Kaya (2020) öğrenci, öğretmen ve velilerin oluşturduğu bu bütünsel yapıyı okuma yazma eylemlerinin alışkanlık haline getirilmesiyle açıklamıştır. Bu görüş aile, çevre ve eğitim öğretim ortamlarının rolünü işlevsel bir ihtiyaç olarak merkeze almaktadır. Bu noktada işlevsellik niteliği kullanılan yöntem, teknik ve modellere dayandırılmıştır. Program yapısı ve öğrencilerin sahip olduğu yaş gereği farklı uygulamalara başvurulmaktadır. Ancak uygulamaların etkililik durumları mevcut konum, sunulan firsatlar, süreç içerisinde izlenen yollara göre farklılaşmakta ve çeşitli sonuçları literatüre yansıtmaktadır (Babayiğit ve Gültekin, 2019).

Böylesi önemli bir dersin işlenişi ve etkili bir okuma yazma becerisinin kazandırılması sürecinde bireysel farklılıklara, kültürel yapıya, elde edilebilen firsatlara bağlı olarak çeşitli sorunlar meydana gelebilmektedir. Ortaya çıkan temel sorunlar öğrenci özellikleri, öğretmen nitelikleri, öğrenme ortamları ya da program yapısından kaynaklanabileceği gibi çözümlenemediğinde ilerleyen dönemlerde meydana gelebilecek başkaca sorunlara da zemin hazırlayabilmektedir. Sorunlara karşı alınacak önlemler ve buna bağlı olarak sunulabilecek öneriler eğitim öğretim sürecinde yer alan kişiler tarafindan alg1 ve yaşantılara bağlı olarak değerlendirilebilmektedir. Eğitim araştırmalarında da temel hareket noktası bu sorunlar ve onlara yönelik çözüm önerileri getirmek olduğundan dikkatle incelenmeleri önemlidir (Sarıbaş ve Babadă̆, 2015).

Araştırma konusu ile ilgili gerçekleştirilen çalışmalara bakıldığında Ütkür'ün (2018) ve Güven ve K1lıç (2017)'ın, hayat bilgisi dersini konu alan araştırmaları ders içeriğinde kullanılan yöntem ve etkinlik bağlamında incelediği görülmektedir. Bunun yanı sıra Akaydın ve Kaya (2015) hayat bilgisi dersi kapsamında ulusal indeksli dergilerde yer alan araştırmaları yöntemsel ögelere bağlı olarak, Yılmaz ve Göçen (2019) hayat bilgisi dersi konulu araştırmaları yayın bilgisi ve yöntem temelli nitelikler bazında incelemiştir. Yılmaz ve Kaya (2020) ilkokuma yazma öğretimi boyutunda gerçekleştirilen çalışmaları araştırma konusu, sınıf düzeyi ve yöntemsel açıdan içerik analizi kapsamında incelemiştir. Benzer şekilde ilkokuma yazma ögretimini konu alan ulusal ve uluslararası dergilerde yayımlanan kimi araştırmalarda yöntemsel açıdan nitelikleriyle birlikte ilişkili oldukları alan ve hedef kitle açısından değerlendirmeler yapıldığı anlaşılmaktadır.

Bilimsel araştırma alanlarının temel dayanak noktasını oluşturan bu değerlendirmeler eğitim araştırmalarında özellikle lisansüstü tez çalışmalarında uygun yöntem ve yaklaşımlar ile incelenmektedir. $\mathrm{Bu}$ araştırmalar, gerçekleştirildiği dönemler doğrultusunda sundukları bulgu ve sonuçlarla ilgili dönemin özelliklerini, dönemin eğitsel süreçlerini ve mevcut eğitim fırsatlarını da ortaya koyabilmektedir. Söz konusu araştırmalar sistemli şekilde değişimi izlemeyi, farklılıkları bütünsel boyutta değerlendirmeyi sağlayabilmekte ve yıllara bağlı olarak ortaya çıkan gelişmeleri yorumlama imkanı da tanıyabilmektedir. 
Literatürde yer alan araştırmalar hayat bilgisi dersi ve ilk okuma yazma öğretimi konusunda çoğunlukla yöntemsel düzeyde bir incelemeye odaklanmıştır. Araştırmalarda yer alan dokümanlar genel kapsamda ilgili makale ya da lisansüstü tez çalışmalarını içermektedir. Bu sebeple anılan ders ve ilk okuma yazma becerisinin kazandırılması konularında gerçekleştirilen üst düzey araştırmalar olarak nitelendirilebilen doktora tezlerinin incelenmesi mevcut durumu anlamaya, gerçekleştirilmesi planlanan yeni araştırmalar konusunda araştırmacılara yardımcı olacaktır.

\subsection{Araştırmanın Amacı}

$\mathrm{Bu}$ araştırmada hayat bilgisi dersi ve ilk okuma yazma öğretimi kapsamında gerçekleştirilen doktora tez çalışmalarını temel araştırma boyutları açısından inceleyebilmek amaçlanmıştır. Bu amaç doğrultusunda YÖK tez veri merkezinde erişime açık şekilde kayıtlı bulunan hayat bilgisi ve ilk okuma yazma konularında gerçekleştirilmiş doktora tezlerinin; genel dağılımı, amaçları, kullanılan yöntem ve ulaşılan sonuçları yönüyle betimlemesi gerçekleştirilmiştir.

\section{YÖNTEM}

Bu çalışmada 2020 TR Dizin Dergi Değerlendirme Kriterleri 8. maddesinde belirtilen araştırma ve yayın etiğine uyulmuştur.

\subsection{Araştırma Deseni}

$\mathrm{Bu}$ araştırmada hayat bilgisi ve ilk okuma yazma öğretimi becerisini ele alan Türkçe dersi kapsamında gerçekleştirilmiş olan doktora tezleri doküman analizi tekniği ile incelenmiştir. Çalışma grubunda yer alan dokümanlar belirlenen alt boyutlara yönelik olarak incelenmiş ve alt boyutlar arası ilişkiler sistematik bir biçimde analiz edilmiştir (Wach, 2013). Belirlenen konu hakkında ele alınan çalışmaları çeşitli yönleriyle analiz etmek ve mevcut durumlar hakkında değerlendirmeler yapılabilmesi amacıyla kullanılan bu inceleme yöntemi geçmişten günümüze değişen araştırma yapısını ortaya koymanın yanında elde edilen sonuçların sürece yansımasını göstermektedir. Bu bağlamda var olan durumların sürece yansıması araştırma sistematiğine bağlı olarak şekillenmektedir (Yin, 2013).

\section{2. Çalışma Grubu}

Doktora tez çalışmalarının incelendiği bu araştırma kapsamında dokümanların içeriğine göre iki farklı çalışma grubu oluşturulmuştur. YÖK tez veri tabanında kayıtlı ve erişilebilir tarih olarak 1994 yılından başlayarak 2020 yılına dek gerçekleştirilmiş olan Hayat Bilgisi dersine yönelik toplam 27 doktora tezi araştırmanın ilk boyuttaki çalışma grubunu oluşturmaktadır. Buna ilave olarak yine erişime açık bulunan 2000 yılından 2020 yılına dek Türkiye'de ilk okuma yazma öğretimi bağlamında gerçekleştirilen ve bu yönde içeriğe sahip olan toplam 19 doktora tezi araştırmanın diğer çalışma grubunu oluşturmaktadır.

Elde edilen verilere ilişkin nitelikli yorumlama yapılabilmesi ve mevcut durumların birbiriyle ilişkilendirilebilmesi için çalışma grubuna dahil edilen dokümanlar araştırma alt amaçlarına uygun biçimde seçilmiştir. Belirlenen inceleme boyutları doğrultusunda araştırmaya yön vermek amacıyla ölçüt örnekleme ile örneklem seçimi tamamlanmıştır. 


\subsection{Veri Toplama ve Veri Analizi}

İlk aşamada YÖK Ulusal Tez Merkezi'nde erişime açık bulunan ve belirlenen araştırma boyutlarına uygunluğu yönüyle elemeler yapılarak dokümanlara ulaşılmıştır. Ardından erişilen dokümanlar sistematik olarak incelenip çalışmaların hayat bilgisi dersi ve ilk okuma yazma öğretimi kapsamında amaç ve çalışma grubu açısından uygunluk durumları kontrol edilmiştir. Çalışmaların alt amaçlara yönelik incelenebilmesi için araştırmacılar tarafından temel inceleme kategorileri oluşturulmuştur. Bu kategoriler 3 öğretim üyesi ve 2 lisansüstü eğitim öğrencisinden alınan görüşlere dayalı olarak tekrar düzenlenmiş, bu bağlamda geçerlik ve tutarlılığa dayalı güvenirlik çalışması gerçekleştirilmiştir. İnceleme kategorilerine bağlı olarak araştırmalardan elde edilen alt kategoriler görüşler doğrultusunda anahtar kelimeler şeklinde düzenlenmiştir.

Ardından tüm çalışmalar yıllara göre dağılım yönüyle incelenerek araştırma amacı, araştırma yöntemi ve elde edilen sonuçlar boyutları ile raporlaştırılmıştır. Veri analizi aşamasında frekans ve yüzde değerlerinden yararlanılarak kimi bulgular nicelleştirilerek sunulmuştur.

\section{BULGULAR}

Araştırma kapsamında toplanan veriler temel olarak tezin tamamlandığ yıl, tezin amacı, tezde kullanılan yöntem-desen ve ulaşılan sonuçlar boyutları dikkate alınacak şekilde bulgulaştırılarak sunulmuştur. Buna bağlı olarak hayat bilgisi dersi ve ilk okuma yazma öğretimi konusunda gerçekleştirilen doktora tezlerinin incelenmesine ilişkin bulgular bu başlıklar altında sırasıyla ayrı ayrı ele alınmıştır.

\subsection{Doktora Tez Çalışmalarının Tamamlandığı Yıl Değişkeni Açısından Durumlarına İlişkin Bulgular}

Hayat bilgisi dersi ve ilk okuma yazma öğretimi kapsamında gerçekleştirilen doktora tez çalışmalarının gerçekleştiği yıllar açısından dağılımı sırasıyla Tablo 1 ve Tablo 2'de sunulmuştur.

\subsubsection{Hayat Bilgisi Dersi Kapsamında Gerçekleştirilen Doktora Tezlerinin Yıllara Göre Dağglımı}

Yıllara göre dağılım kapsamında hayat bilgisi dersine yönelik doktora tez çalışmalarına ilişkin bulgular Tablo 1'de görülmektedir:

Tablo 1: Hayat Bilgisi Dersi Kapsamında Gerçekleştirilen Doktora Tezlerinin Yıllara Göre Dă̆llımı

\begin{tabular}{cccc}
\hline Yllar & Frekans & \% \\
\hline 2020 & 3 & 11,11 \\
2018 & 2 & 7,40 \\
2017 & 3 & 11,11 \\
2016 & 3 & 11,11 \\
2015 & 2 & 7,40 \\
2014 & 2 & 7,40 \\
2013 & 1 & 3,70 \\
2012 & 1 & 3,70 \\
\hline
\end{tabular}


Tablo 1 (Devam): Hayat Bilgisi Dersi Kapsamında Gerçekleştirilen Doktora Tezlerinin Yıllara Göre Dağılımı

\begin{tabular}{cccc}
\hline Yıllar & Frekans & \% \\
\hline 2011 & 1 & 3,70 \\
2010 & 1 & 3,70 \\
2009 & 1 & 3,70 \\
2007 & 3 & 11,11 \\
2005 & 2 & 7,40 \\
2003 & 1 & 3,70 \\
1994 & 1 & 3,70 \\
Toplam & $\mathbf{2 7}$ & $\mathbf{1 0 0}$ \\
\hline
\end{tabular}

Tablo 1 incelendiğinde 1994 yılından 2020 y1lına dek hayat bilgisi dersi kapsamında toplam 27 adet doktora tez çalışmasının gerçekleştirildiği görülmektedir ( $\mathrm{n}=27)$. Bu çalışmaların 3'er kez olmak üzere en fazla 2020, 2017, 2016 ve 2007 y1llarında gerçekleştirildiği belirlenmiştir (n=3). Özellikle 2013 yılı sonrasında çalışma sayılarındaki artış dikkat çekmektedir. $\mathrm{Bu}$ durumun mevcut doktora programlarının sayısındaki artış, öğretim programlarında meydana gelen değişimler ile yeni yöntem teknik uygulamalarının merkeze alınması gibi nedenlerden kaynaklandığı düşünülebilir.

\subsection{2. İk Okuma Yazma Ö̆̆gretimi Kapsamında Gerçekleştirilen Doktora Tezlerinin Yıllara Göre Dă̆ılımı}

Erişim sağlanan ilk okuma yazma becerisi konulu doktora tez çalışmalarının tamamlandığı yıllara göre dağılımı Tablo 2'de görülmektedir:

Tablo 2: Illk Okuma Yazma Öğretimi Kapsamında Gerçekleştirilen Doktora Tezlerinin Yıllara Göre Dă̆gllımı

\begin{tabular}{ccc}
\hline Yıllar & Frekans & \% \\
\hline 2019 & 1 & 5,26 \\
2018 & 1 & 5,26 \\
2017 & 1 & 5,26 \\
2016 & 1 & 5,26 \\
2015 & 4 & 21,05 \\
2013 & 1 & 5,26 \\
2012 & 1 & 5,26 \\
2011 & 1 & 5,26 \\
2010 & 1 & 5,26 \\
2009 & 2 & 10,52 \\
2008 & 2 & 10,52 \\
2007 & 1 & 5,26 \\
2005 & 19 & 5,26 \\
2000 & 1 & $\mathbf{1 0 0}$ \\
Toplam & 26
\end{tabular}


Tablo 2 incelendiğinde 2000 y1lından 2020 y1lına dek ilk okuma yazma öğretimi becerisi kapsamında toplam 19 adet doktora tez çalışmasının gerçekleştirildiği görülmektedir $(n=19)$. Bu çalışmaların sayıca en fazla 2015 yılında $(n=5)$ gerçekleştirildiği belirlenmiştir. Bununla birlikte 2008 ve 2009 yıllarında 2'şer kez konu ile ilgili tamamlanmış tez çalışması olduğu ( $\mathrm{n}=2)$, diğer yıllarda ise yalnızca 1 kez doktora tezlerinde bu konuya yer verildiği gözlemlenmiştir $(n=1)$.

\subsection{Doktora Tez Çalışmalarının Belirlenen Amaçlar Yönüyle Durumlarına İlişkin Bulgular}

Hayat bilgisi dersi ve ilk okuma yazma öğretimi kapsamında gerçekleştirilen doktora tez çalışmalarının belirlenen amaçlara ilişkin dağılımı Tablo 3 ve Tablo 4 'te sunulmuştur.

\subsubsection{Hayat Bilgisi Dersi Kapsamında Gerçekleştirilen Doktora Tezlerinin Amaçlarına Göre Dă̆ılımı}

Belirledikleri amaçlar yönüyle hayat bilgisi dersine yönelik doktora tez çalışmalarına ilişkin bulgular Tablo 3'te görülmektedir:

Tablo 3: Hayat Bilgisi Dersi Kapsamında Gerçekleştirilen Doktora Tezlerinin Amaçlara Göre Dă̆ılımı

\begin{tabular}{|c|c|c|}
\hline Amaçlar & Frekans & $\%$ \\
\hline Beceri Kazanımı & 6 & 15,38 \\
\hline Program Değerlendirmesi & 6 & 15,38 \\
\hline Değer Kazanımı & 4 & 10,25 \\
\hline Öğrenme-öğretme yaklaşımlarının etkisi & 3 & 7,69 \\
\hline Yöntem Teknik Kullanımının Etkililiği & 2 & 5,12 \\
\hline Kavram Öğrenimi & 2 & 5,12 \\
\hline Değerlerin Kazandırılma Şekli & 2 & 5,12 \\
\hline Uygulama etkililiği & 2 & 5,12 \\
\hline Öğretim Modellerinin Etkisi & 2 & 5,12 \\
\hline Öğrenme Stilleri Etkisi & 1 & 2,56 \\
\hline Kazanımların kalıcılığı & 1 & 2,56 \\
\hline Ders Başarısı & 1 & 2,56 \\
\hline Tutum değişimi & 1 & 2,56 \\
\hline Öğrenme Ortamlarının Etkisi & 1 & 2,56 \\
\hline Kavram Öğretimi & 1 & 2,56 \\
\hline Materyal Etkisi & 1 & 2,56 \\
\hline Sınıf İklimi Değiş̧imi & 1 & 2,56 \\
\hline Ders İşlenişi & 1 & 2,56 \\
\hline Ders İçerikleri & 1 & 2,56 \\
\hline Toplam & 39 & 100 \\
\hline
\end{tabular}

Tablo 3 incelendiğinde hayat bilgisi dersine yönelik gerçekleștirilen doktora tezlerinin belirlenen 19 farklı amaç ifade biçimiyle literatürde yer aldığı görülmektedir (n=19). Belirledikleri amaçlar doğrultusunda araştırma yöntemi, uygun desen seçimi gerçekleştirilerek örneklem ve veri toplama şekli 
belirlenmiştir. Hayat bilgisi dersine yönelik bu çalışmalar arasında ders kapsamında beceri kazanımı ve hayat bilgisi dersi öğretim programının değerlendirilmesi sıkça ele alınan amaçlar olarak dikkat çekmektedir. Beceri kazanımına odaklanılan çalışmalarda özellikle sosyal gelişimin ele alındığı ve günlük yaşam becerilerinin öğrencilere ders kapsamında kazandırılma durumlarının incelendiği gözlenmiştir. Benzer şekilde bu becerilerin ve program kazanımlarının birbiriyle uyumu gerçekleştirilen program değerlendirme çalışmaları ile sağlanmıştır.

Değer kazanımına odaklanılan ve bu amaç doğrultusunda incelemelerin yapıldığı araştırmalarda değer öğretimi esas alınarak mevcut program ders içerikleri arasındaki ilişkiler incelenmiştir. Okul öncesi eğitimle birlikte ilkokul düzeyinde değer öğretiminin hayat bilgisi dersi kapsamında ele alınması, sosyal ve duyuşsal gelişim özelliklerini de beraberinde getirerek ders amacını bütünsel bir şekilde yansıtmaktadır. $\mathrm{Bu}$ boyutta değer kazanımının gelişim alanlarıyla ilişkilendirildiği doktora tez çalışmalarına da rastlanmıştır.

\subsection{2. İlk Okuma Yazma Ö̆̆gretimi Kapsamında Gerçekleştirilen Doktora Tezlerinin Amaçlarına Göre Dă̆ılımı}

Amaçlara göre dağılım kapsamında ilk okuma yazma öğretimine yönelik doktora tez çalışmalarına ilişkin bulgular Tablo 4'te görülmektedir:

Tablo 4: Illk Okuma Yazma Öğretimi Kapsamında Gerçekleştirilen Doktora Tezlerinin Amaçlara Göre Dă̆gllımı

\begin{tabular}{ccc}
\hline Amaçlar & Frekans & $\%$ \\
\hline Öğretim Yöntemleri Etkisi & 5 & 21,73 \\
Yeterli Beceri Düzeyi & 4 & 17,39 \\
Program Değerlendirmesi & 4 & 17,39 \\
Sorunlar ve Çözüm Önerileri & 3 & 13,04 \\
Çoklu Ortam Araçlarının Etkisi & 2 & 8,69 \\
Farkındalık Düzeyleri & 1 & 4,34 \\
Düşünme Stilleri Etkisi & 1 & 4,34 \\
Sosyal-Duygusal Uyum & 1 & 4,34 \\
Zeka Düzeyi & 1 & 4,34 \\
İşbirliği Süreci & 1 & 4,34 \\
Toplam & $\mathbf{2 3}$ & $\mathbf{1 0 0}$ \\
\hline
\end{tabular}

Tablo 4 incelendiğinde ilk okuma yazma öğretimini konu alan doktora tezlerinin belirledikleri amaçlar yönüyle dağılımı görülmektedir. Çalışma grubunda yer alan tez çalışmalarında "öğretim yöntemleri etkisini sınama" sıkça ele alınan tez amacı olarak dikkat çekmektedir. Benzer şekilde "yeterli beceri düzeyi" ve "program değerlendirme" amaçlarını benimseyen çalışmalara da sıklıkla rastlanmıştır. $\mathrm{Bu}$ amaçlara odaklanılan çalışmalarda basamaklar arası geçişle birlikte bir uyum sürecini ifade eden ilk okuma yazma öğretiminin nitelikli ve mevcut programa uygun şekilde gerçekleştirilmesi hedeflenmektedir. Özellikle doktora tez çalışmalarında denel işlem sürecinde kullanılan yaklaşımların başarısının ispatına odaklanıldığından öğrencilerin süreç içerisinde aktif olabileceği, kalıcı öğrenmelerin gerçekleşebileceği uygulamalara ağırlık verildiği söylenebilir. 
Araştırmalarda belirlenen diğer amaçlar incelendiğinde sorunları ve çözüm önerilerini belirleyebilme amacını benimseyen 3 doktora tezinin çalışma grubunda yer aldığg görülmektedir $(\mathrm{n}=3)$. Geçiş sürecinde meydana gelen öğrenme - öğretme süreçlerine dayalı ortam, içerik, amaç değişimi, uyuma dayalı bazı sorunları beraberinde getirmektedir. Bu sorunların incelenmesi ve ilişkili çözüm önerileri getirilmesi okuma yazmaya bağlı süreçlerin uyumlu ve istendik şekilde gerçekleştirilebilmesi açısından önem taşımaktadır.

\subsection{Doktora Tez Çalışmalarının Belirlenen Yöntem ve Desenlerine İlişkin Bulgular}

Hayat bilgisi dersi ve ilk okuma yazma öğretimi kapsamında gerçekleştirilen doktora tez çalışmalarının yürütülen yöntem ve araştırma desenine ilişkin dağılımı Tablo 5 ve Tablo 6 'da sunulmuştur.

\subsubsection{Hayat Bilgisi Dersi Kapsamında Gerçekleştirilen Doktora Tezlerinde Kullanılan Yöntem ve Desen Dă̆̆lımı}

Araştırma yöntemi ve araştırma desenine göre dağılım kapsamında hayat bilgisi dersine yönelik doktora tez çalışmalarına ilişkin bulgular Tablo 5 'te görülmektedir:

Tablo 5: Hayat Bilgisi Dersi Kapsamında Gerçekleştirilen Doktora Tezlerinin Yöntem ve Desen Boyutuna İlişkin

\section{Dağılımı}

\begin{tabular}{ccc}
\hline Yöntem ve Desen & Frekans & $\%$ \\
\hline Karma Araşırıma Deseni & 13 & 48,14 \\
• Delphi Paneli & 1 & 3,70 \\
• Eylem Araştırması & 1 & 3,70 \\
- Durum Çalışması & 1 & 3,70 \\
- Deneysel Desen & 4 & 14,81 \\
• Yöntem Çeşitlemesi & 1 & 3,70 \\
• Gömülü Deneysel Desen & 2 & 7,40 \\
- Yakınsayan Paralel Desen & 1 & 3,70 \\
- Eşitlenmemiş Kont. Gruplu Deneysel Desen & 1 & 3,70 \\
• İki Faktörlü Deneysel Desen & 1 & 3,70 \\
Nitel Araştırma Deseni & 7 & 25,92 \\
• Eylem Araştırması & 3 & 11,11 \\
• Durum Çalışması & 2 & 7,40 \\
• Olgu Bilim Deseni & 1 & 3,70 \\
• Alan Araştırması & 1 & 3,70 \\
Nicel Araştırma Yöntemleri & 7 & 25,92 \\
• Deneysel Desen & 3 & 11,11 \\
• Özel Araştırma Deseni & 1 & 3,70 \\
• Betimsel Tarama Deseni & 3 & 11,11 \\
Toplam & $\mathbf{2 7}$ & $\mathbf{1 0 0}$ \\
\hline
\end{tabular}


Tablo 5 incelendiğinde hayat bilgisi dersine yönelik gerçekleştirilen doktora tezlerinin 3 farklı yöntemde ve bu yöntemlere bağlı olarak toplam 16 farklı desende yürütüldüğü görülmektedir. Elde edilen frekans değerlerine bağlı olarak 3 yöntem arasında karma yönteme uygun şekilde yürütülen araştırmaların sıklığı 13 frekans değeriyle göze çarpmaktadır $(n=13)$. Bu araştırmalar arasında en fazla yarı deneysel desenin kullanılmış olduğu görülmektedir. Söz konusu araştırmalarda deney ve kontrol gruplarından ön test ve son testler ile birlikte uygulama aşamasına ilişkin nitel boyutta veri toplama süreci gerçekleştirilmiştir. Özellikle deney gruplarında yer alan katılımcıların deneysel süreç hakkındaki görüşleri elde edilen nicel boyuttaki verileri destekleyerek bulguların birbiriyle ilişkilendirilmesini sağlamıștır.

Yöntem sürecinde ele alınan diğer desenlerin kullanımı incelendiğinde araştırmalarda nitel ve nicel desenlerin 7'şer kez olmak üzere aynı sıklıkla yer aldığg 1 görülmektedir ( $\mathrm{n}=7)$. Karma yönteme ilişkin desenlerde olduğu gibi bu yöntemlerin ele alındığı araştırmalarda da araştırma sürecinde uygulamanın varlığı öne çıkmaktadır. Nicel boyutta denel işlemlerin gerçekleştiği, nitel boyutta ise algı ve görüşlere odaklanılarak mevcut durumun aksine değişimin izlendiği uygulamaların doktora tezlerinde sıklıkla tercih edildiği görülmektedir. Bu kapsamda nicel araştırma yöntemleri boyutunda deneysel desen $(n=3)$, nitel araştırma yöntemleri boyutunda ise eylem araştırması deseni $(n=3)$ araştırmacılar tarafindan sıklıkla tercih edilmiştir.

\subsection{2. İk Okuma Yazma Öğretimi Kapsamında Gerçekleştirilen Doktora Tezlerinde Kullanılan Yöntem ve Desen Dă̆̆lımı}

Araştırma yöntemi ve araştırma deseni açısından ilk okuma yazma öğretimine yönelik gerçekleștirilen doktora tez çalışmalarına ilişkin inceleme sonuçları Tablo 6'da görülmektedir:

Tablo 6: Illk Okuma Yazma Öğretimi Kapsamında Gerçekleştirilen Doktora Tezlerinin Yöntem ve Desen Boyutuna İlişkin Dă̆ılımı

\begin{tabular}{ccc}
\hline Yöntem ve Desen & Frekans & \% \\
\hline Karma Araşırma Deseni & 8 & 42,10 \\
• Program Değerlendirmesi Deseni & 1 & 5,26 \\
• Durum Çalışması & 2 & 10,52 \\
• Deneysel Desen & 2 & 10,52 \\
• Yöntem Çeşitlemesi & 1 & 5,26 \\
• Tarama Deseni & 2 & 10,52 \\
Nitel Araştırma Deseni & 6 & 31,57 \\
• Eylem Araştırması & 3 & 15,78 \\
• Durum Çalışması & 2 & 10,52 \\
• Doğal İnceleme Deseni & 1 & 5,26 \\
Nicel Araştırma Yöntemleri & 5 & 26,31 \\
• Deneysel Desen & 3 & 15,78 \\
• Tarama Deseni & 2 & 10,52 \\
Toplam & $\mathbf{1 9}$ & $\mathbf{1 0 0}$ \\
\hline
\end{tabular}

Tablo 6 incelendiğinde ilk okuma yazma öğretimine yönelik gerçekleştirilen doktora tezlerinin 3 farkl1 yöntemde ve bu yöntemlere bağl1 olarak toplam 10 farklı desende yürütüldügüü görülmektedir. Elde edilen frekans değerlerine bağlı olarak 3 yöntem arasında karma yönteme uygun şekilde yürütülen araştırmaların sıklığı 8 frekans değeriyle göze çarpmaktadır $(n=8)$. Bu araştırmalar arasında en fazla 
durum çalışması, tarama ve deneysel desenlerin kullanılmış olduğu görülmektedir. Söz konusu araştırmalarda uygulanan ölçeklere ilişkin verilerle birlikte görüşme, gözlem verileri araştırma sürecine dahil edilmiştir. $\mathrm{Bu}$ kapsamda nicel ve nitel boyutta ortaya çıan araştırma verileri birbiri ile ilişkilendirilerek araştırma kapsamında belirlenen amaca yönelik sonuçlara ulaşılmasını sağlamıştır.

Yöntem sürecinde ele alınan diğer desenlerin kullanımı incelendiğinde araştırmalarda nitel desenlerin $6 \mathrm{kez}(\mathrm{n}=6)$, nicel desenlerin ise $5 \mathrm{kez}$ kullanıldığı görülmektedir $(\mathrm{n}=5)$. Bu boyutta da elde edilen bulguların daha çok deneysel uygulamalara bağlı olarak ortaya çıktığı, bu sebeple eylem araştırması deseni $(n=3)$ ve deneysel desene $(n=3)$ araştırmalarda sıklıkla yer verildiği görülmektedir.

\subsection{Doktora Tez Çalışmalarında Ulaşılan Sonuçlara İlişkin Bulgular}

Hayat bilgisi dersi ve ilk okuma yazma öğretimi kapsamında gerçekleştirilen doktora tez çalışmalarının ulaştı̆̆ sonuçlara ilişkin dağılımı Tablo 7 ve Tablo 8'de sunulmuştur.

\subsubsection{Hayat Bilgisi Dersi Kapsamında Gerçekleştirilen Doktora Tezlerinin Ulaşılan Sonuçlara İlişkin Dağılımı}

Elde edilen araştırma sonuçları kapsamında hayat bilgisi dersine yönelik doktora tez çalışmalarına ilişkin bulgular Tablo 7'de görülmektedir:

Tablo 7: Hayat Bilgisi Dersi Kapsamında Gerçekleştirilen Doktora Tezlerinin Sonuç Boyutuna İlişkin Dă̆ılımı

\begin{tabular}{|c|c|c|}
\hline Sonuçlar & Frekans & $\%$ \\
\hline Akademik Başarı & 8 & 14,03 \\
\hline Tutum & 6 & 10,52 \\
\hline Düşünce Becerileri Gelişimi & 6 & 10,52 \\
\hline Beceri-Kazanım-Materyal Uyumsuzluğu & 5 & 8,77 \\
\hline Duygusal Beceri Gelişimi & 3 & 5,26 \\
\hline Sosyal Beceri Gelişimi & 3 & 5,26 \\
\hline Kalıcılık & 3 & 5,26 \\
\hline Değer Kazanımı & 2 & 3,50 \\
\hline Sorumluluk Kazanımı & 2 & 3,50 \\
\hline Ders Kitaplar1-Program Uyumu & 2 & 3,50 \\
\hline Materyal Etkisi & 2 & 3,50 \\
\hline Aktif Katılım & 2 & 3,50 \\
\hline Öğretmen Eğitimine Duyulan İhtiyaç & 2 & 3,50 \\
\hline İşbirliği Ve İletişim & 2 & 3,50 \\
\hline Kavram Algılama/İlişkilendirme & 1 & 1,75 \\
\hline Demokratik Sınıf Ortamlarının Oluşumu & 1 & 1,75 \\
\hline Güvenli Sınıf Ortamlarının Oluşumu & 1 & 1,75 \\
\hline Motivasyon & 1 & 1,75 \\
\hline Kaynak Kullanımı & 1 & 1,75 \\
\hline Rol Kazanımı & 1 & 1,75 \\
\hline Günlük Yaşam İle Uyumluluk & 1 & 1,75 \\
\hline Bilişsel Gelişim & 1 & 1,75 \\
\hline Program Ögelerine Ayrılan Süre & 1 & 1,75 \\
\hline Toplam & 57 & 100 \\
\hline
\end{tabular}


Tablo 7 incelendiğinde hayat bilgisi dersine yönelik gerçekleştirilen doktora tezlerinin ulaştığ sonuçlara yönelik kategorik durumu görülmektedir. Tabloda yer alan kategoriler arasında sıkça karşılaşılan ifadeler yüksek frekans değerleriyle akademik başarı $(n=8)$, tutum $(n=6)$, beceri-kazanımmateryal uyumsuzluğu, $(n=5)$ düşünce becerileri gelişimi $(n=5)$ olarak sıralanmaktadır

Özellikle deneysel ve eylem araştırması desenlerinde yürütülen çalışmalarda ele alınan akademik başarı ölçümü, uygulamalar sonucu 8 araştırmada farklılık göstermektedir $(n=8)$. Bu farklılıklar tek gruplu araştırmalarda uygulama sonrası, deney ve kontrol gruplarının var olduğu araştırmalarda ise deney grubu lehine anlamlı etki oluşumu şeklinde ortaya konmuştur. İncelenen çalışmalarda öğrenme stillerinin, medya araçları ve materyal kullanımının, beyin temelli öğrenme yaklaşımının, proje tabanlı öğrenme yaklaşımının, çoklu zeka kuramının, kavram analizi stratejisinin ve örnek olay yönteminin akademik başarı yönünden hayat bilgisi dersine yönelik öğrenmelere katkı sağladığı belirlenmiştir.

Akademik başarıya etkinin incelendiği araştırmalarda bu ölçümün yanı sıra tutum etkisi incelendiğinde 6 araştırmada uygulamalar sonrası tutum düzeylerinde farklılıklar görülmektedir. $\mathrm{Bu}$ farklı1ıklar uygulama sonrası ve deney grupları lehine anlamlı sonuçlar ortaya çıkarmıştır. Çalışmalarda öğrenme ortamlarının, Sosyal Beceri Eğitim Programı'nın, etkin öğrenme yaklaşımının, ders içeriğine bağlı materyal kullanımının ve kavram analizi stratejisinin hayat bilgisi dersine yönelik öğrencilerin olumlu tutum geliştirmesine katkı sağladığı belirlenmiştir.

Araştırma sonuçlarında öne çıkan bir başka boyut düşünce becerilerinin gelişimi şeklinde ifade edilmiştir. Bu değişim ele alınan değişkenlere göre yansıtıcı, eleştirel, yaratıcı gibi üst düzey düşünme becerilerinin kazanımına yönelik ele alındığı gözlemlenmiştir. Felsefi düşünce kazanımını içeren uygulamalar, sorgulama temelli etkinlikler, öğrenme ortamları, beyin temelli öğrenme ve değer öğretimi uygulamalarının öğrenme - öğretme süreçlerinde düşünce becerilerini desteklediği belirlenmiştir.

Doküman analizi ve öğretmen görüşlerine bağlı olarak öğretim programlarının değerlendirildiği araştırmalarda hayat bilgisi dersine yönelik kazandırılması hedeflenen becerilerin, programda yer alan kazanımların ve ders içeriğine yönelik kullanılan materyaller ile uyumsuz olarak nitelendirildiği görülmektedir.

\subsection{2. İlk Okuma Yazma Öğretimi Kapsamında Gerçekleştirilen Doktora Tezlerinin Ulaşılan Sonuçlara İlişkin Dă̆̆lımı}

Elde edilen araştırma sonuçları kapsamında ilk okuma yazma öğretimine yönelik doktora tez çalışmalarına ilişkin bulgular Tablo 8'de görülmektedir:

Tablo 8: Illk Okuma Yazma Öğretimi Kapsamında Gerçekleştirilen Doktora Tezlerinin Sonuç Boyutuna İlişkin Dağılımı

\begin{tabular}{ccc}
\hline Sonuçlar & Frekans & \% \\
\hline Yeterli Beceri Düzeyi & 7 & 17,94 \\
Akademik Başarı & 6 & 15,38 \\
Uygun Yaklaşım ve Uygulamalar & 6 & 15,38 \\
Sürece Dönük Güçlükler & 5 & 12,82 \\
Tutum & 2 & 5,12 \\
Araştırmalara Duyulan İhtiyaç & 2 & 5,12 \\
Yetişkin Desteği Etkisi & 1 & 2,56 \\
İletişim & 1 & 2,56 \\
\hline
\end{tabular}

Anadolu Üniversitesi Ĕ̆itim Fakültesi Dergisi (AUJEF), 5(3), 324-347 
Tablo 8 (Devam): İlk Okuma Yazma Öğretimi Kapsamında Gerçekleştirilen Doktora Tezlerinin Sonuç Boyutuna

\begin{tabular}{|c|c|c|}
\hline Sonuçlar & Frekans & $\%$ \\
\hline Kalıcılık & 1 & 2,56 \\
\hline Yüksek Farkındalık Düzeyi & 1 & 2,56 \\
\hline Öğretmen Nitelikleri & 1 & 2,56 \\
\hline Öğrenci Seviyesine Uygunluk & 1 & 2,56 \\
\hline Yüksek Özyeterlilik Düzeyi & 1 & 2,56 \\
\hline Akran İşbirliği Etkisi & 1 & 2,56 \\
\hline Okuma Yazma Sentezi & 1 & 2,56 \\
\hline Mesleki Gelişim İhtiyacı & 1 & 2,56 \\
\hline Kültürel Destek Etkisi & 1 & 2,56 \\
\hline Toplam & 39 & 100 \\
\hline
\end{tabular}

Tablo 8 incelendiğinde ilk okuma yazma öğretimine yönelik gerçekleştirilen doktora tezlerinin ulaştı̆̆ sonuçlara iliş̧in kategorik yapı görülmektedir. Bu kategoriler arasında sıkça karşılaşılan ifadeler yüksek frekans değerleriyle Yeterli Beceri Düzeyi ( $\mathrm{n}=7)$, Akademik Başarı $(\mathrm{n}=6)$, Uygun Yaklaşım ve Uygulamalar ( $\mathrm{n}=6)$ ve Sürece Dönük Güçlükler $(\mathrm{n}=5)$ olarak öne çıkmaktadır.

Yeterli Beceri Düzeyi boyutunda ortaya çıkan sonuçlar okuma ve yazma becerilerine yönelik ifadeler taşımaktadır. Bu kapsamda okuma hızı, yazma hızı, okuduğunu anlama, cümle çözümleme becerilerinin gerçekleştirilen öğrenme - öğretme süreçlerine ve bu süreçte ele alınan uygulamalara bağlı olarak öğrencilere yeterli düzeyde kazandırıldığı belirlenmiştir. Bu boyut Akademik Başarı ve Uygun Yaklaşım/Uygulamalar sonucu ile bağlantılı olup beceri gelişimine yönelik uygulamaların gerçekleştĭgi grupların lehine anlamlı fark ortaya koyan sonuçların ortaya çıkmasına imkan sağlamış görünümdedir.

Okul öncesi eğitimden ilkokul basamağına geçişle birlikte uyum sürecinin beraberinde getirdiği birtakım güçlükler gerçekleştirilen araştırma sonuçlarına yansımıştır. Bu güçlüklerin okuma yazma öğretimine hazırlık aşamasında sesi hissetme ve tanıma, iletişim, hece/kelime/cümle/metin oluşturma boyutlarında meydana geldiği belirlenmiştir. Ayrıca özellikle deney ve kontrol grupları ile yürütülen çalışmalarda kontrol grubu öğrencilerinin uygulama süreci kapsamında okuma ve yazım yanlışları bir diğer güçlük boyutunu ifade etmektedir.

\section{TARTIŞMA ve SONUÇ}

Araştırmada elde edilen bulgular değerlendirilerek ulaşılan sonuçlar aşağıda sıralanmıştır:

Gerçekleştirilen tez çalışmalarının yıllara göre dağılımı incelendiğinde her iki alanda da bu dağılımın 2015 ve sonrası yıllarda yoğunlaştığı görülmektedir. Anılan zaman dilimindeki yoğunlaşmanın temel olarak yeni açılan sınıf eğitimi doktora programlarındaki sayıca artıştan kaynaklandığı söylenebilir. Nitekim anılan dönemde bu duruma bağlı olarak programlarda öğrenim görmekte olan öğrenci sayısı ve programlarda görev alan akademisyen sayısındaki artışta bu durumu açıklar niteliktedir. Ayrıca benimsenen yeni yaklaşımlar ve bu yaklaşımlara bağlı olarak kullanımı önerilen yöntem ve teknikler güncel araştırma konularının oluşumuna katkı sağlayarak araştırmacılara araştırma alanları ile ilgili fikir vermektedir. Benzer şekilde bilimsel araştırma yöntemleri kapsamında yeni yaklaşım ve uygulamaların etkin kullanımı da son yıllarda gerçekleştirilen araştırmalardaki artışa katk1 sağlayan bir başka faktör olarak değerlendirilebilir. Akdemir ve Karakuş (2016) tarafından 
gerçekleştirilen araştırmada yaratıcı drama alanında gerçekleştirilen lisansüstü tez çalışmalarının benzer şekilde güncel özellikler taşıdığı görülmektedir. Öğrencinin merkeze alındığı, öğrenci ilgi ve ihtiyaçlarına dayalı öğrenme hedeflerinin oluşturulduğu mevcut program kapsamında yaratıcı drama yönteminin kullanımı ve bilimsel araştırmalara yansıması göze çarpmaktadır. Yıllara göre dağılım kapsamında bir başka benzer sonuç Balcı (2012) tarafından gerçekleştirilen çocuk edebiyatı konulu lisansüstü çalışmaların incelenmesi adlı araştırmada da ortaya konmuştur.

Ele alınan araştırma amacı boyutunda çalışma gruplarında yer alan doktora tezlerinin özellikleri incelendiğinde her iki alanda da mevcut program değerlendirmeleri ve derse yönelik kazandırılması hedeflenen beceriler üzerine odaklanıldığı görülmektedir. Benzer şekilde Polat (2017) hayat bilgisi dersi kapsamında lisansüstü tez çalışmalarının program, öğrenme - öğretme süreçleri kapsamında gerçekleştirildiği sonucuna ulaşmıştır. Ayrıca ders ve çalışma kitaplarında derse yönelik becerilerin yer alma durumlarının incelendiği araştırmalara rastlanmıştır. Şimşek (2019) ise hayat bilgisi ve sosyal bilgiler dersleri bağlamında incelediği araştırmalarda araştırma konularının çoğunlukla öğretim strateji, yöntem ve teknik üzerinde yoğunlaştığı sonucuna ulaşmıştır. Yöntem ve stratejilere dayalı sonuçlara ulaşan Yılmaz ve Kaya (2020) ilk okuma yazma ve Türkçe öğretimine yönelik tez çalışmalarının bu araştırma konuları kapsamında çoğunlukla ses temelli cümle yönteminin etkililiği üzerinde durulmuştur. Yılmaz ve Göçen (2019) hayat bilgisi dersi öğretim programını temel alan araştırmalarda konuların çoğunlukla beceri ve değer öğretimini ele aldığı sonucuna ulaşmıştır.

$\mathrm{Bu}$ amaçların birbiri ile ilişki halinde olduğu, belirtilen sıklık boyutuna da yansıyan biçimiyle temel eğitim düzeyinde öğrencilere yaşam becerileri kazandırmaya yönelik bir çabanın ortaya konmaya çalışıldığ 1 söylenebilir. Bu beceriler güncel yaşam özellikleri ile ilişkilendirilerek mevcut programa yansımakta ve uygun yaklaşımlar ile uygulamalara duyulan ihtiyacı ön plana çıkarmaktadır. $\mathrm{Bu}$ kapsamda hem hayat bilgisi dersine yönelik hem de ilk okuma yazma becerisi kazandırmaya ilişkin olarak sıklıkla araştırma amaçlarına konu olan ilkokul basamağına geçiş sürecinin ne denli önemli olduğu da anlaşılmaktadır.

İncelenen doktora tezlerinde araştırmacıların amaçlara uygun olarak tercih ettikleri yöntemlerin ağırlıklı olarak deneysel desen ve eylem araştırması olduğu görülmektedir. Bu sonuç Kırat ve Güven (2020) tarafından gerçekleştirilen meta-analiz çalışmasında elde edilen yöntem ve desen bazındaki bulgularla farklılık göstermektedir. Söz konusu araştırmada yüksek lisans tez çalışmaları daha yoğunlukta olmak üzere tüm lisansüstü tez çalışmaları kapsama alınmış, erişilen çalışmalarda kullanılan yöntem ve desenlerin genel incelemesi gerçekleştirilmiştir. Araştırmada özellikle yüksek lisans tezlerinde tarama ve durum çalışmaları kapsamında var olan durumun incelemesi şeklinde bir yöntem tercihinin dikkat çekici şekilde ön plana çıktığı belirlemiş̧lerdir. Ancak mevcut araştırmada ise hayat bilgisi dersi ve ilk okuma yazma öğretimini konu alan doktora tezleri bu boyutta incelendiğinde doktora programı alanında durum değerlendirmelerinin aksine uygulama etkisi işe koşularak değişen yapının etkilerini belirleyebilmek amaçlanmaktadır. Varışoğlu ve ark. (2013) tarafından gerçekleştirilen araştırmada bu kapsamda elde edilen sonuçlar deneysel desen bazında benzer nitelikler taşımaktadır. Nicel yöntemde gerçekleştirilen araştırmaların yoğunlukta olduğu Türkçe Eğitimi araştırmalarında deneysel desende yürütülen çalışmaların sıkça gerçekleştirilme durumu göze çarpmaktadır. Erbağcı ve Kaf (2020) hayat bilgisi dersine yönelik incelediği araştırmalarda çoğunlukla nicel yöntemin kullanıldığ 1 sonucuna ulaşmıştır. Bu durumun oluşmasında doktora tezlerinden beklenen özgünlük ya da yenilik niteliğinin etkili olduğu düşünülebilir. Benzer şekilde deneysel çalışmalar kapsamında incelenen değişim ve etki süreçleri Boulianne (2009) tarafından gerçekleştirilen internet kullanımının sosyal yaşantıya etkisi konulu meta analiz araştırmasında benzer yöntem kullanımına dayalı olarak internet kullanımına ilişkin istatistiksel sonuçlar ele alınmıştır. Araştırmada, olumlu ve olumsuz etkiyle birlikte ortalama etki boyutlarının incelenmesine odaklanarak sosyal yaşantı üzerine değişimler incelenmiştir. Değiş̧imlere

Anadolu Üniversitesi Ĕ̆itim Fakültesi Dergisi (AUJEF), 5(3), 324-347 
yönelik gerçekleştirilen incelemede çalışmaların doktora tez çalışmalarında olduğu gibi bağımlı değişken etkisinin ölçümü üzerine odaklanıldığı görülmektedir. Etkinin incelendiği bir başka araştırma olan Dignath ve Büttner (2008) tarafindan gerçekleştirilen çalışmada farklı strateji kullanımlarının ve öz düzenleme becerisinin ilişkisini ele alan araştırmalara yer verilmiştir. Araştırma sonuçları müdahaleler ile birlikte yaşam boyu öğrenme stratejilerinin temel alınarak öz düzenlemeye ilişkin olumlu etkilerin varlığını ortaya koymuştur.

Hayat bilgisi dersi ve ilk okuma yazma öğretimi kapsamında elde edilen sonuçlar değerlendirildiğinde çoğu araştırmada beceri edinimi amacına odaklanılarak yüksek beceri düzeyi ile ilişkili durumların varlığını ortaya koyduğu görülmektedir. Benzer şekilde Friso-Van den Bos ve ark. (2013) tarafından gerçekleştirilen araştırmada ilkokul çocuklarında zihinsel süreçler ve bu süreçlere bağlı olarak gelişen beceri düzeylerinin incelendiği çalışmalardan elde edilen bulgu ve sonuçlar birçok çalışmada performans ölçütlerinin işe koşulduğunu göstermektedir. Bu doğrultuda çalışma belleği bileşenlerinin performansa dayalı olarak yüksek korelasyon değerlerine sahip olduğu ve beceri edinimine olumlu katkı sağladığı belirlenmiştir. Mevcut araştırmada da olduğu gibi beceri kazanımını sağlayan boyutlar program ögeleri ile ilişki halinde olup gelişim alanlarını desteklemekte ve performans ile ölçülmektedir.

Diğer açıdan araştırmaların çoğunda akademik başarı ve tutum düzeylerinin yüksek olduğu sonuçlarına ulaşılmıştır. Lisansüstü tez çalışmaları kapsamında doktora tez çalışmalarında seçilen araştırma yönteminin oluşturduğu aşama ve uygulamalar mevcut durumu incelemenin aksine değişimi ön plana alarak öne çıkabilecek sonuçlara odaklanmaktadır. Bu kapsamda farklı uygulama ve yaklaşımların incelenerek öğrenme - öğretme süreçlerine sağladığı katkıların belirlenmesi araştırmacıların güncel araştırma hedeflere ulaşmasına olanak sağlamaktadır. Doğan ve Özçakmak (2014) tarafindan gerçekleştirilen dinleme becerisi eğitimi konulu lisansüstü tez çalışmalarının incelendiği araştırmada uygulamalara bağlı olarak farklı yaklaşım ve yöntemlerin kullanımı benzer sonuçları beraberinde getirmiştir. Aynı açıdan Zheng ve ark. (2016) tarafından gerçekleştirilen dizüstü bilgisayar ortamlarının etkisi yönünde gerçekleştirilen araştırmada dergi makaleleri ve doktora tez çalışmaları incelenmiştir. Mevcut araştırma ile benzer şekilde araştırma amacı ve bulgularına odaklanılarak öğrencilerin akademik başarı ve tutumlarına yönelik artışların meydana geldiği görülmüştür. Mevcut araştırmada olduğu gibi farklı yöntem ve teknik kullanımının süreç içerisinde etkili olduğu akademik başarı ve derse yönelik tutumda anlamlı farklılıklar ortaya koyduğu belirlenmiştir.

Araştırma sonucu kapsamında incelemelerin yapıldığı farklı alanlardaki çalışmalara bakıldığında Kale, Karagöz ve Nur (2021) eğitim ve sosyal bilimler alanında gerçekleştirilen lisansüstü tez çalışmalarının kuramsal bir temele dayandırılmadan gerçekleştirildiği sonucuna ulaşmıştır. Ballı ve Yapucuoğlu (2021) Suriyeli çocukların eğitim öğretim yaşantılarına ilişkin gerçekleştirilen tez çalışmalarını inceledikleri makalelerinde araştırma kapsamında yer alan tezlerin çoğunlukla nitel araştırma yöntemi temelindeki desenler ile gerçekleştirildiği sonucuna ulaşmışlardır. Söz konusu araştırmadan farklı olarak elde edilen sonuçlar olumlu sonuç ve olumsuz sonuç şeklinde kategorilendirilerek araştırma önerileri boyutunda da ayrıca incelemeler gerçekleştirilmiştir.

\section{1. Öneriler}

Araştırmanın temel amaçları ve bu amaçlara bağlı olarak elde edilen sonuçlar doğrultusunda gerçekleştirilebilecek öneriler şu şekildedir:

- Araştırmanın alt amaçları doğrultusunda incelenen çalışma amacı, yöntemi ve sonuçları bakımından doktora tezlerinde çoğunlukla uygulamaya dayalı veri toplama süreçlerinin 
gerçekleştirildiği görülmektedir. Gelecek araştırmalarda veri toplama aşaması uygulama boyutunda gerçekleştirilen çalışmalar incelenerek bu araştırmalarda izlenen yöntemsel süreçler detaylandırılabilir.

- İncelenen tez çalışmalarında kullanılan araştırma desenlerine dayalı olarak veri toplama araçlarının çoğunlukla araştırmacılar tarafından geliştirildiği belirlenmiştir. Buna dayalı olarak bu süreçte çeşitli ölçümler yapılarak aracın örneklem ya da çalışma gruplarına göre uygunluğu test edilmiştir. Gelecek araştırmalarda bu ölçümlerin çeşitliliği ve geçmişten günümüze kullanım sıkl1kları incelenebilir.

- Araştırmada yer alan doktora tez çalışmalarının çoğunlukla doküman inceleme, öğretmen görüşleri ve öğrenci uygulamalarına dayalı olarak gerçekleştirildiği görülmektedir. Araştırmanın bu boyutu kendi içerisinde değerlendirilerek ortaya çıkan benzer ve farklı sonuçlar birbiri ile ilişkilendirilerek temelde ulaşılan noktalar vurgulanabilir. 


\section{KAYNAKLAR}

Akaydın, B. ve Kaya, S. (2015). Türkiye'de ilkokul hayat bilgisi ve sosyal bilgiler alaninda yapilan ve ulusal indeksli dergilerde yayinlanan araştirmalara yönelik bir inceleme. Mustafa Kemal Üniversitesi Sosyal Bilimler Enstitüsü Dergisi, 12(30), 251-264.

Akcaalan, M. ve Arslan, S. (2016). Yaşam boyu öğrenme: Teori ve uygulama. Konya: Eğitim Kitabevi

Akdemir, H., ve Karakuş, M. (2016). Yaratıı drama yönteminin akademik başarı üzerine etkisi: Bir meta-analiz çalışması. International Journal of Active Learning, 1(2), 55-67.

Babayiğit, Ö. ve Gültekin, M. (2019). İlk okuma yazma öğretiminde oyunla öğretim yöntemi uygulamaları. Anadolu Journal of Educational Sciences International, 9(2), 450-483.

Balc1, A. (2012). Türkiye'de çocuk edebiyatı üzerine hazırlanan lisansüstü tezler hakkında bir meta-analiz çalışması. Mustafa Kemal Üniversitesi Sosyal Bilimler Enstitüsü Dergisi, 9(17), 195-206.

Ballı, F. E. ve Yapucuoğlu, M. D. Türkiye'deki Suriyeli Çocukların Eğitim Öğretim Yaşantılarına İlişkin Tezlerin İncelenmesi. Türk Eğitim Bilimleri Dergisi, 19(1), 505-524.

Boulianne, S. (2009). Does internet use affect engagement? A meta-analysis of research. Political communication, 26(2), 193-211.

Demirel, Ö. (2015). Eğitimde program geliştirme: Kuramdan uygulamaya. 23. Baskı. Ankara: Pegem Akademi

Dignath, C., \& Büttner, G. (2008). Components of fostering self-regulated learning among students. A meta analysis on intervention studies at primary and secondary school level. Metacognition and learning, 3(3), 231-264.

Doğan, Y., ve Özçakmak, H. (2014). Dinleme becerisinin eğitimi üzerine yapıllan lisansüstü tezlerin değerlendirilmesi. Ana Dili Eğitimi Dergisi, 2(2), 90-99.

Erbağcı, N. ve Kaf, Ö. (2020). Hayat Bilgisi Dersi Öğretim Programı İle İlgili Yapılan Çalışmaların Çeşitli Değişkenler Açısından İncelenmesi. Adnan Menderes Üniversitesi Eğitim Fakültesi Eğitim Bilimleri Dergisi, 11(1), 103-115.

Erbasan, Ö., ve Erbasan, Ü. (2020). Sınıf öğretmenlerinin ilk okuma yazma öğretimi sürecinde karşılaştığı sorunlar. Ana Dili Eğitimi Dergisi, 8(1), 113-125.

Fazlığlu, Y. (2011). Erken çocukluk gelişimi ve eğitimi. 2. Baskı. Ankara: Kriter Yayıncılık

Friso-Van den Bos, I., Van der Ven, S. H., Kroesbergen, E. H., ve Van Luit, J. E. (2013). Working memory and mathematics in primary school children: A meta-analysis. Educational research review, 10, 29-44.

Gözel, Ü. (2021). Birinci Sınıf Hayat Bilgisi Dersi Okulumuzda Hayat Ünitesinde Yer Alan Değerlerin İncelenmesi. OPUS Uluslararası Toplum Araştırmaları Dergisi, 17(34), 1-1.

Güven, S. ve K1lıç, Z. (2017). Hayat bilgisi dersinde kullanılan öğretim yöntemlerinin etkililiği konusunda yapılan lisansüstü tezlerin içerik analizi. Türk Ĕgitim Bilimleri Dergisi, 15(2), 200-223.

Kale, M., Karagöz, S., ve Nur, İ. (2021). Eğitim ve Sosyal Bilimler Alanında Kardeş İlişkileri Konusunda Tezlerin İncelenmesi. Mersin Üniversitesi Ĕ̈itim Fakültesi Dergisi, 17(1), 148-160.

Karatay, H., Külah, E., ve Kaya, S. (2020). Okuma alışkanlığını geliştirme yöntem, teknik ve modelleri. Okuma Yazma Eğitimi Araştırmaları, 8(1), 89-107.

Kırat, E. ve Güven, B. (2020). İlkokul hayat bilgisi dersi kapsamında gerçekleştirilen lisansüstü eğitim tezlerine ilişkin bir inceleme. Çukurova Araştırmaları, 6(1), 85-108.

Ministerium für Kultus, Jugend und Sport Baden-Württemberg. (2016). Bildungsplan 2016.

Polat, H. (2017). Türkiye'de 2005-2017 Tarihleri Arasında Hayat Bilgisi Dersi ile İlgili Yapılmış Lisansüstü Çalışmalar Üzerine Bir Değerlendirme. Electronic Turkish Studies, 12(33). 
Sarıbaş, S., ve Babadağ, G. (2015). Temel eğitimin temel sorunları. Anadolu Ĕ̆itim Liderliği ve Öğretim Dergisi, 3(1), 18-34.

Senemoğlu, N. (2015). Gelişim, öğrenme ve öğretim. 24. Baskı. Ankara: Yargı Yayınevi

Sukawati, N. N., Gunawan, I., Ubaidillah, E., Maulina, S., ve Santoso, F. B. (2020, November). Human resources management in basic education schools. In 2nd Early Childhood and Primary Childhood Education (ECPE 2020) (pp. 292-299). Atlantis Press.

Şimşek, A. (2019). Hayat bilgisi ve sosyal bilgiler dersi ile ilgili yapılan lisansüstü tezlerin çeşitli değişkenler açısından incelenmesi (Master's thesis, Necmettin Erbakan Üniversitesi Eğitim Bilimler Enstitüsü).

Ütkür, N. (2018). Hayat Bilgisi Derslerinde Kullanılan Yöntem Ve Etkinliklerin Tespiti: Lisansüstü Tezlerin İncelenmesi. Celal Bayar Üniversitesi Sosyal Bilimler Dergisi, 16(01), 101-122.

Varışoğlu, B., Şahin, A., ve Göktaş, Y. (2013). Türkçe eğitimi araştırmalarında eğilimler. Kuram ve Uygulamada Eğitim Bilimleri, 13(3), 1767-1781.

Wach, E. (2013). Learning about qualitative document analysis.

Yavuzer, H. (2014). Çocuğunuzun ilk 6 yılı. 31. Basım. İstanbul: Remzi Kitabevi

Yaycı, L. (2005). Gelişim ve öğrenme. (Ed. B. Aydın). Bilişsel gelişim ve dil gelişimi. Ankara: Nobel Yayın Dağıtım

Yılmaz, F. ve Göçen, S. Hayat Bilgisi Öğretim Programına İlişkin Yapılan Araştırmalara Yönelik Bir İnceleme. Medeniyet Eğitim Araştırmaları Dergisi, 3(2), 79-86.

Yılmaz, D. ve Kaya, S. İlk Okuma Yazma ve Türkçe Öğretimi İle İlgili Tezlerin İncelenmesi. Turkish Studies, 15 ,1.

Yin, R. K. (2017). Durum çalışması araştırması uygulamaları. (çeviri: Prof. Dr. İlhan Günbayı). 3. Basımdan çeviri. Ankara: Nobel Akademi.

Zheng, B., Warschauer, M., Lin, C. H., \& Chang, C. (2016). Learning in one-to-one laptop environments: A meta analysis and research synthesis. Review of Educational Research, 86(4), 1052-1084.

\section{Araştırmada İncelenen Çalışmaların Listesi}

\section{Hayat Bilgisi Dersi Konulu Doktora Tez Çalışmaları}

Arık, S. (2016). Hayat bilgisi dersinde liderlik becerisinin kazandırllmasının sınıf öğretmeni görüşlerine göre incelenmesi (Doktora Tezi, Anadolu Üniversitesi Eğitim Bilimleri Enstitüsü, Eskişehir).

Bektaş, M. (2007). Hayat bilgisi dersinde ailelerin çoklu zeka kuramı hakkında bilgilendirilme biçimlerinin ve ögrencilerin farklı baskın zeka gruplarında yer almalarının proje başarıları ve tutumlarına etkisi (Doktora Tezi, Gazi Üniversitesi Eğitim Bilimleri Enstitüsü, Ankara).

Bütün, E. (2015). Medya destekli öğretimin hayat bilgisi dersinde akademik başarıya ve öğrenmede kalıcılı̆̆a etkisi (Doktora Tezi, Ondokuz Mayıs Üniversitesi Eğitim Bilimleri Enstitüsü, Samsun).

Demir, F. (2018). Değer öğretimi yaklaşımlarına göre hayat bilgisi dersinde değerler ĕ̌itimi (Doktora Tezi, İnönü Üniversitesi Eğitim Bilimleri Enstitüsü, Malatya).

Demir, S. (2007). Illköğretim okulu hayat bilgisi dersi programının öğretmen görüşlerine göre incelenmesi (Doktora Tezi, İnönü Üniversitesi Sosyal Bilimler Enstitüsü, Malatya).

Durmuş, T. (2017). Hayat bilgisi dersinde kullanılan farklılaştırılmış öğretim modelinin, öğrencilerin başarı düzeyleri ve tutumlarına etkisi (Doktora Tezi, Ondokuz Mayıs Üniversitesi Eğitim Bilimleri Enstitüsü, Samsun).

Dündar, H. (2007). Kavram analizi stratejisinin ögrencilerin kavram ögrenme başarısı ve hayat bilgisi dersine ilişkin tutumlarına etkisi (Doktora Tezi, Gazi Üniversitesi Eğitim Bilimleri Enstitüsü, Ankara).

Anadolu Üniversitesi Ĕ̆itim Fakültesi Dergisi (AUJEF), 5(3), 324-347 
Ekin, C. Ç. (2017). Zihinsel engelli çocuklara hayat bilgisi kavramlarının öğretiminde akıllı oyuncaklar (Doktora Tezi, Orta Doğu Teknik Üniversitesi Fen Bilimleri Enstitüsü, Ankara).

Erbaş, A. A. (2020). Hayat bilgisi dersi kapsaminda değerler eğitimi üzerine bir araştırma: Beklentiler, uygulamalar ve öneriler (Doktora Tezi, İstanbul Üniversitesi Cerrahpaşa Lisansüstü Eğitim Enstitüsü, İstanbul).

Gündoğan, A. (2017). Hayat bilgisi dersinde otantik görev temelli öğrenme ortamlarının, ögrencilerin derse yönelik tutumlarına ve ögrrenme süreçlerine yansıması (Doktora Tezi, Anadolu Üniversitesi Eğitim Bilimleri Enstitüsü, Eskişehir).

Gündüz, M. (2014). Illköğretim 3. sinıf hayat bilgisi dersinde "sorumluluk" değerinin proje tabanl öğrenme yaklaşımı ile ögretiminin akademik başarı ve tutuma etkisi (Doktora Tezi, Gazi Üniversitesi Eğitim Bilimleri Enstitüsü, Ankara).

Hasırcı, Ö. K. (2005). İlköğretim 3. sinıf hayat bilgisi dersinde görsel öğrenme stiline göre düzenlenen öğretimin ögrencilerin akademik başarı ve kalıcllı̆̆ına etkisi (Doktora Tezi, Çukurova Üniversitesi Sosyal Bilimler Enstitüsü, Adana).

Hüner, S. B. (2018). Sokratik sorgulama temelli etkinliklerin hayat bilgisi dersinde başart ve kalıcllğa etkisinin incelenmesi: bir eylem araştırması (Doktora Tezi, İstanbul Üniversitesi Cerrahpaşa Lisansüstü Eğitim Enstitüsü, İstanbul).

Kalaycı, N. (1994). İlkokul ii. sinıf hayat bilgisi dersini okutan öğretmenlerin bu dersteki etkinliklere ayırdikları sürenin değerlendirilmesi (Doktora Tezi, Hacettepe Üniversitesi Sosyal Bilimler Enstitüsü, Ankara).

Kaya, N. B. (2020). Hayat bilgisi ve sosyal bilgiler derslerinde çocuklar için felsefe: bir eylem araş̧tırması (Doktora Tezi, Marmara Üniversitesi Eğitim Bilimleri Enstitüsü, İstanbul).

Kaya, S. (2009). Hayat bilgisi öğretim programındaki duyuşsal yoğunluklu kazanımların değerlendirilmesi (Doktora Tezi, Abant İzzet Baysal Üniversitesi Sosyal Bilimler Enstitüsü, Bolu).

Kılıç, Z. (2015). Hayat bilgisi dersinde öğrencilerin yaşam becerilerinin geliştirilmesinde etkin öğrenme uygulamaları (Doktora Tezi, Anadolu Üniversitesi Eğitim Bilimleri Enstitüsü, Eskişehir).

K1lınç, M. (2011). İlköğretim hayat bilgisi programı karakter eğitimi boyutunun öğrencilerin tipik performanslarına dayalı olarak değerlendirilmesi: Kirş̧ehir örneği (Doktora Tezi, Atatürk Üniversitesi Eğitim Bilimleri Enstitüsü, Erzurum).

Ocak, G. (2003). Illköğretim okulları 3. sinıf hayat bilgisi ders içeriğinin öğretmen görüşlerine göre, bazı değişkenler açısından yeterlilik düzeyi (Standart belirleme-Erzurum il örneği) (Doktora Tezi, Atatürk Üniversitesi Sosyal Bilimler Enstitüsü, Erzurum).

Palavan, Ö. (2012). Hayat bilgisi dersinde beyin temelli öğrenmenin öğrencilerin başarllarına, tutumlarına ve eleştirel düşünme becerilerine etkisi (Doktora Tezi, Ondokuz Mayıs Üniversitesi Eğitim Bilimleri Enstitüsü, Samsun).

Şimşek, S. (2005). Örnekolaya dayal öğretimin ilkögrretim hayat bilgisi dersinde akademik başariya ve öğrenmede kalıcılı̆ga etkisi (Doktora Tezi, Anadolu Üniversitesi Eğitim Bilimleri Enstitüsü, Eskişehir).

Talşı, E. (2013). Illkokul Türkçe, matematik ve hayat bilgisi derslerinde ögrretim materyali olarak şarkaların kullanılmasının ögrencilerin başarı ve tutum gelişimleri üzerindeki etkisi (Doktora Tezi, Gazi Üniversitesi Eğitim Bilimleri Enstitüsü, Ankara).

Taneri, P. O. (2010). Yapılandırmacı hayat bilgisi programının uygulanması: bir durum çalı̧̧ması (Doktora Tezi, Orta Doğu Teknik Üniversitesi Sosyal Bilimler Enstitüsü, Ankara).

Tezcan, Ö. (2016). Illkokul 3. sinlf hayat bilgisi dersinde sosyal beceri eğitim programının etkisinin sinanmast: Bir eylem araştırması (Doktora Tezi, Marmara Üniversitesi Eğitim Bilimleri Enstitüsü, İstanbul). 
Uzunkol, E. (2014). Hayat bilgisi öğretiminde kullanılan dĕgerler ĕgitimi programının öğrencilerin özsaygı düzeyleri, sosyal problem çözme becerileri ve empati düzeylerine etkisi (Doktora Tezi, Gazi Üniversitesi Eğitim Bilimleri Enstitüsü, Ankara).

Ütkür, N. (2016). Örnek olay yönteminin hayat bilgisi dersinde uygulanmasına yönelik bir eylem araştırması (Doktora Tezi, Marmara Üniversitesi Eğitim Bilimleri Enstitüsü, İstanbul).

Yıldırım, G. (2020). İlkokul düzeyinde öğrencilere kazandırılması gerekli temel yaşam becerilerinin hayat bilgisi dersi bağlamında analizi (Doktora Tezi, Gazi Üniversitesi Eğitim Bilimleri Enstitüsü, Ankara).

\section{İlk Okuma Yazma Öğretimi Konulu Doktora Tez Çalışmaları}

Aktay, E. G. (2015). İlk okuma yazma öğretiminde akran işbirliği (Doktora Tezi, Anadolu Üniversitesi Eğitim Bilimleri Enstitüsü, Eskişehir).

Babayiğit, Ö. (2016). İlk okuma yazma öğretiminde oyunla öğretim yöntemi uygulamaları (Doktora Tezi, Anadolu Üniversitesi Eğitim Bilimleri Üniversitesi, Eskişehir).

Ball, J. K. (2010). How the instructional reading and writing program in kindergarten contributes to the reading and writing achievement of students in Grade 1: A single-case study(Doctoral dissertation, Walden University, Minnesota).

Bay, Y. (2008). Ses temelli cümle yöntemiyle ilk okuma yazma ögretiminin değerlendirilmesi (Ankara ili örnĕgi) (Doktora Tezi, Gazi Üniversitesi Eğitim Bilimleri Enstitüsü, Ankara).

Bayat, S. (2012). Stake’in uygunluk/olasılık modeline göre ilkokuma yazma programının değerlendirilmesi (Doktora Tezi, Abant İzzet Baysal Üniversitesi Eğitim Bilimleri Enstitüsü, Bolu).

Cardona, A. (2018). Preservice teachers sense of efficacy to teach reading and writing and familiarity with readers and writers workshop (Doctoral Dissertation, Caldwell University, New Jersay).

Gözüküçük, M. (2015). Anadili Türkçe olmayan ilkokul öğrencilerine ilkokuma yazma öğretiminde karşılaşılan sorunlar ve çözüm önerileri (Doktora Tezi, Pamukkale Üniversitesi Eğitim Bilimleri Enstitüsü, Denizli).

Jou, Y. A. E. (2008). The effect of email keypal project on the enhancement of reading and writing performance of elementary school-aged EFL students in Taiwan (Doctoral Dissertation, Alliant International University, San Diego).

Krisell, M. R. (2015). Teachers' perceptions of teaching reading and writing through the use of play-based developmentally appropriate practice and constructivist approaches (Doctoral Dissertation, The University of Memphis).

Küçükünal, I. S. (2019). Okuma yazma problemi olan çocuklarda gazi okuma yazma eğitim programının etkililiğinin işitsel işlemleme açısından incelenmesi (Doktora Tezi, Gazi Üniversitesi Eğitim Bilimleri Enstitüsü, Ankara).

Leary, S. E. (2000). The effect of guided reading instruction under the balanced reading program on first year reading and writing success at high point primary school in clearwater, florida (Doctoral Dissertation, Kean University, New Jersey).

Malova, I. (2017). Integrated reading-writing instruction for elementary school emergent bilingual students (Doctoral Dissertation, University of Miami, Florida).

McGuyer, K. (2011). Primary teachers' perspectives on teaching reading to students with dyslexia in the general education classroom (Doctoral Dissertation, Walden University, Minnesota).

Obalar, S. (2009). İlköğretim birinci sınıf öğrencilerinin ilk okuma yazma becerileri ile sosyal duygusal uyum ve zeka düzeyleri arasındaki ilişkinin incelenmesi (Doktora Tezi, Marmara Üniversitesi Eğitim Bilimleri Enstitüsü, İstanbul).

Anadolu Üniversitesi Ĕğitim Fakültesi Dergisi (AUJEF), 5(3), 324-347 
Şahin, A. (2005). İlk okuma-yazma öğretiminde kullanılan çözümleme ve bireşim yöntemlerinin uygulamalı olarak karşılaştırılması (Doktora Tezi, Gazi Üniversitesi Eğitim Bilimleri Enstitüsü, Ankara).

Tunçer, B. K. (2013). Öğretmen adaylarının ilk okuma yazma ögretimi dersindeki akademik başarıları, biliş üstü farkındalık düzeyleri, düşünme stilleri ve tutumları arasındaki ilişkiler (Doktora Tezi, Çanakkale Onsekiz Mart Üniversitesi Eğitim Bilimleri Enstitüsü, Çanakkale).

Turan, M. (2007). Illkögretim 1. sınıf Türkçe dersi ilk okuma yazma programında uygulanan ses temelli cümle yönteminin uygulamadaki etkililiği (Doktora Tezi, Fırat Üniversitesi Sosyal Bilimler Enstitüsü, Elazı̆̆).

Yıldız, S. (2009). İlkokuma yazma öğretiminde çoklu ortam uygulamalarının etkililiği (Doktora Tezi, Abant İzzet Baysal Üniversitesi Sosyal Bilimler Enstitüsü, Bolu).

Zhao, R. (2015). Exploring reading and writing connections in the synthesis writing of multilingual students in a second language writing classroom (Doctoral Dissertation, The Ohio State University, Columbus). 


\section{EXTENDED ABSTRACT}

The primary school period, in which basic skills are acquired with the beginning of school age and continuity is ensured in terms of development processes, includes the first years of education life. This process is also called the social environment in which basic structures are established and continuity is ensured. Especially these years correspond to critical periods within the scope of skill acquisition and directly emphasize the importance of the process. In this sense, together with pre-school education, primary school period creates the first social environment of individuals and ensures the continuity of social life. In this context, the stimulating environment is expressed as the building block of healthy development (Senemoğlu, 2015 ; Yavuzer, 2014).

When this period from the past to the present is examined and the structural features of the period are considered, it is seen that the learning effect is emphasized in shaping the behaviors. In contrast to a structure in which spontaneous development occurs in all areas such as social, cognitive, personality, moral and similarly, it is known that interaction takes place in the process. In this structure, it is possible to see the traces of socio-cultural variables and social impact. In this dimension, as a result of the interaction of the natural framework that the child had before the broad social life, it leaves its place to the cultural framework (Yayc1, 2005). This comprehensive impact process that occurs directs future lives and represents a preparation process.

The primary school period, which is in the said critical period, has been examined in different dimensions as a subject of research areas from past to present and has contributed to the planning of educational processes. Studies on the primary school level were frequently associated with the lessons taught in this period, and the situations related to the process were examined. The dimensions between development and learning were examined by associating the multiple developments of individuals with learning processes. In this context, the lessons that are the source of the basic skills aimed to be acquired in the primary school period and the contents discussed reflect the learning approaches adopted and reveal the functioning of the process with the teaching programs. The dimensions dealt with change with the developments experienced. This situation reflects on the researches on the subjects and presents the changes in the learning-teacher process. Thus, the current situation in the addressed objectives, contents, learning processes and evaluation elements is evaluated by following scientific research processes.

In this study, it is aimed to examine the graduate education researches in which the basic courses taught in the primary school period are subject to different dimensions. Documents related to the determined subject are limited to doctoral dissertations on life studies lesson and first reading and writing teaching. The documents that are open to access from the YÖK's National Thesis Center and Proquest database have been reached. Thesis studies were analyzed on the basis of the purpose they dealt with, the method-pattern used and the result. In addition, the distribution according to the years in which the thesis work was completed was examined. The expressions obtained as a result of the data analysis were converted into numericals with frequency and percentage values and presented in the full text as tables.

When the findings obtained as a result of the data analysis are examined on the basis of the subobjectives of the research, the resulting frequency and percentage values in terms of the year show that the thesis studies on the life studies lesson were frequently completed in 2020, 2017, 2016 and 2007. In the thesis studies on first reading and writing education in terms of the year, this situation is emphasized with the year 2015 .

When the thesis studies were examined purpose, it was determined that the research objectives for life studies lesson and teaching first reading and writing were formed within the framework of skill / value acquisition, program evaluation, learning-teaching approaches. In this case, as a result of the 
examination, it can be said that the research purpose structure in both fields has similar characteristics in terms of subject.

As a result of the examination carried out in the dimension of method and design, it is seen that the thesis studies within the scope of life studies lesson and first reading and writing teaching are mostly carried out within the framework of mixed method, and accordingly, the number of studies conducted in the experimental design and action research design is high. Quantitative and qualitative research methods were preferred less frequently, and this situation was reflected in the choice of pattern.

When the thesis studies were examined within the scope of the research results, it was seen that the results related to the skill acquisition, increase in academic achievement, and program suggestions related to life studies lesson and first reading and writing teaching were frequently reached. This dimension has similar characteristics with the results related to research purposes. These results highlight the theoretical structure addressed within the framework of the research by revealing the importance of social life and skill development shaped by the basic education level. 